\title{
Social Strategy of Ciliwung River Bank Community
}

\author{
Prudensius Maring $^{1 \bowtie}$, Fordolin Hasugian ${ }^{1}$, Retor AW Kaligis ${ }^{1}$ \\ ${ }^{1}$ Sekolah Tinggi Ilmu Sosial dan Ilmu Politik (STISIP) Widuri, Jakarta. \\ Permalink/DOI: http://dx.doi.org/10.15294/komunitas.v7i1.3600
}

Received : Feb 2015; Accepted: March 2015; Published: March 2015

\section{Abstract}

This article explains relation of social economic strategy applied by the community on the setting of watershed area with dinamics and complexity of urban life. To explain the problem, this article use the perspective of ecological anthropology and urban anthropology. This research uses indepth-interview, participatory observation, and focus group discussion. This research was conducted on the community of Ciliwung watershed on Kampung Melayu and Cawang village in East Jakarta. This research shows that the community on Ciliwung watershed area have social organization based on primordial and religion. The social organization have inclusive orientation and have goal to overcome everyday social problem. The community have model of ecological adaptation and socialeconomic strategy that have characteristics of resistance (control, protect, defend, and resist) as response to the uncertainty of policy and involution of Ciliwung watershed development.
\end{abstract}

\begin{abstract}
Abstrak
Tulisan ini menjelaskan hubungan antara strategi sosial ekonomi yang dijalankan masyarakat dalam latar ekologi bantaran sungai dengan kondisi kehidupan perkotaan yang dinamis dan kompleks. Untuk menjelaskan masalah tersebut, penelitian ini menginspirasi kepada perspektif antropologi ekologi dan antropologi perkotaan. Penelitian ini mengacu kepada pendekatan kualitatif dengan menerapkan metode wawancara mendalam, pengamatan terlibat, dan diskusi kelompok terfokus. Penelitian lapangan dilakukan pada masyarakat bantaran sungai Ciliwung di Kelurahan Cawang dan Kelurahan Kampung Melayu, Jakarta Timur. Hasil penelitian memperlihatkan bahwa masyarakat bantaran sungai Ciliwung memiliki organisai sosial berbasis asal-usul daerah dan agama berorientasi inklusif dan bertujuan mengatasi masalah sosial yang dihadapi dalam kehidupan sehari-hari. Masyarakat memiliki pola adaptasi ekologi dan strategi sosial ekonomi berciri bertahan (menguasai, melindungi, bertahan, dan melawan) sebagai respon terhadap ketidakpastian kebijakan dan involusi pembangunan bantaran sungai Ciliwung.
\end{abstract}

Keywords: ciliwung; social-economic strategic; urban community; river bank area; involution

How to Cite: Maring, P., Hasugianı, F., Kaligisı R.A.W. 2015. The Portrait of Social Strategy of Ciliwung River Bank Community. Jurnal Komunitas, 7(1): 102-111. doi:http://dx.doi.org/10.15294/komunitas.v7i1.36oo

(c) 2014 Semarang State University. All rights reserved

\begin{tabular}{l}
\hline Corresponding author : \\
Address: J1.Palmerah Barat No.353 Jakarta Selatan 12210 Jakarta - Indonesia
\end{tabular}




\section{INTRODUCTION}

Flood that occurs repeatedly in the long term can cause not only destruction of property, but also can ignite deviant behavior and poverty. Flood begins reaching elite settlement, center of the economy, and main road. But flood mostly attacks residents in the river banks who are truly struggling to face the rigors of metropolitan life. Up to now, about 71,00o families or about 700,000 people live in the river banks. The fact is, economically, 700,0oo residents of river bank are difficult to find alternative shelter that is safe from flood. Their work varies from pickers, construction workers, street vendors, and prostitutes (Kompas, Wawa: 02/10/2007). A flood in 2007 had caused 55 dead casualties, 320,000 residents' displacement, and trillions of dollars of economic losses.

Various actions that have been made by the victims, in fact, have supported the decline of life quality. Some actions which are taken by the government also show poor strategies and lack of innovative ideas. The phenomenon flood is hard to be ignored because it always happens in front of our eyes, including under the authority of government officials and politicians in this country. By looking at the flooded area, we have witnessed many household items which are damaged. The mud makes it difficult for the people to distinguish between new and old furniture. Many families are reluctant to throw their furniture away. They still collect and wash them for reuse. This habit is repeated from year to year. The success of cleaning and reusing their stuffs becomes a pleasure for them (Maring, 2007).

The economic losses that continue to afflict such as repeating displacement, adjusting housing attic to avoid flood, and mud picking from the furniture can trigger the development of behavior of 'accepting' to contradiction. The incident which recurs has made people to develop coping strategies that tend to be complicated (involutive). Unfortunately, the strategies are interpreted as a common and normal action. Children of flood victims develop "surrender" behavior that is exhibited by their parents for so many years. They will eventually generate the thought that seizing new opportunities in response to flood may be unnecessary. These symptoms indicate the operation of the poverty culture (Oscar Lewis, 1966 Saifuddin, 2007). Those who are involved are very difficult to escape from the poverty trap. In addition, because they have been caught in a vicious circle, they tend to receive the condition of not considering themselves as poor.

Ironically, our actions, especially the government, in responding the floods are still traditional and not innovative. The implemented actions have not touched the fundamental problems to prevent flood, such as implementing conservation in the upstream area, cross-region cooperation, organizing a settlement pattern and setting a convenient drainage network. We mostly start to react when the flood comes. We are poor in preventing and measuring the longterm impact. The actions which are carried out just show that we interpret the flood as a normal phenomenon and part of our lives. Following the mind frame of Max Weber (1947), such social action is seen as a traditional and non-rational action. Such action is done without reflection and learning from the experience (Maring, 2007).

The statement of problem which is discussed in this paper includes: how are some social and economic strategies that are run by river bank communities in response to regular flood and the uncertainty of river bank development policy. This article comes from research on urban involution and socio-economic strategies of Ciliwung river bank. Therefore, this paper is only a snapshot of a holistic picture/large community that is being applied by Ciliwung river bank community. Conceptually, to explain the problem, this research is inspired by the perspective of cultural ecology (ecological anthropology) and urban anthropology. Cultural ecology perspective seeks to explain the socio-economic strategy which is conducted by the community; whereas, urban anthropology perspective seeks to explain the reality of the lives of urban settings which are dynamic, complex, and tends to 
be complicated.

The cultural ecology perspective emphasizes the cultural cores including social, political, and social organization patterns (Geertz, 1963). Geertz's view about the core elements of these cultures provides an entry point to understand the strategy of social, cultural, economic and urban communities that are implemented along the river bank. Socio-economic strategies which are run by the public do not take place in an empty room; they will always be associated with the broader socio-political reality which is experienced by dynamic, complex, and complicated (involutif) society as "urban community." Involution concept is found by some anthropologists to explain the patterns of culture (Geertz, 1963). Involution describes the culture that has reached an established pattern and, if it is not able to make itself stable and dynamic, it will experience a hassle in the inside (involutive) and create stagnation.

Geertz puts an analogy that involution is like the behavior of a painter who, although he is already finished painting, keeps continuing to paint over the same media, so the painting is finally filled with some overlapping and increasingly complicated lines. Geertz constructs theories of agricultural involution from the research on paddy rice in Java. Wetland ecosystem (rice) has the characteristic to give employment. Paddy field which is originally planted once a year has finally developed into twice and even three times a year. The compaction of fertilizers, pesticides, and improved land processing technologies are done to increase the production. Family labors are exploited as much as possible to increase the production. In fact, to add the numbers of labors, family farm will increase the number of child birth. Ironically, although the strategies of production are crammed into the fields more and more, but productivity remains the same.

Geertz explanation shows that the involutive strategy ultimately will able to improve the productivity of fields but the result that is obtained is artificial because, although the result is increasing, it still lo- ses if all inputs are taken into account. The number of people involved, enabling them to only share little results. The situation is called shared poverty (Geertz, 1963). Moreover, the increasing number of family members leads to a fragmentation of wetland, a phenomenon that has implications on the complexity of field division. It can be seen that the effort to increase rice production makes complexity into involution or even stagnation. This phenomenon is called agricultural involution. The explanation of involution concept from this wetlands characteristic can provide inspiration to clarify, whether the setting of river banks in urban areas is going to involution society, which can be seen through the phenomenon of narrowing the flow of the river, building a multi-storing houses, and being reluctant to move after the repeated flood.

To understand the reality of urban life which is dynamic, complex, and complicated, this research is also inspired by approach of urban anthropology. The approach of urban anthropology interprets urban within the context which explains the problem in urban life and the urban issues surrounding it. Urban problems which are subjected to the study of urban anthropology are rooted in urban culture and social institutions that live and thrive in the city. From the main study of the cultural and social institutions, this approach views the existence, essence, and trend of urban people's daily life, patterns of behavior, community life, the economy, relations between ethnic or inter-ethnic, the emergence and consolidation of social groups, hierarchies and social stratification, poverty, slum area, and the issue of settlements, houses, residential as well as various other problems (see Suparlan, 2004).

The view from Suparlan asserts that the study of urban anthropology is not just positioning the urban/city as a physical location or just a place to do research. The studies of urban anthropology perspective must meet the following requirements: (1) study or research is done to be able to define cities or towns which are included in the study as the integral part of the research's conceptual goals. (2) Research should be able to explo- 
re and discover patterns that are empirically applied in the urban life which is examined. (3) Research should use a holistic approach to the city and various interrelationships of the city with the patterns of behavior and cultural patterns with the broader community.

\section{METHODS}

This study used a qualitative approach (Creswell, 2010) to understand the reality of the field. A qualitative approach requires sharpness and precision from researchers to explore and capture the reality of the studied cases. To study the socio-economic strategy, Cawang Village and Kampung Melayu were selected as research locations. To learn the modified strategy approach of community, this research studied the government institutions and officials, as well as some relevant non-governmental organizations at village and city level. A study with qualitative approach regarded the researchers as part of the instruments. The researcher equipped themselves with knowledge of the comparison and study questions as a matter of study, namely: (1) How is the socio-economic strategy developed by urban communities who are affected by repeated flood along the river? (2) What is the reality of involution in the life of urban communities who live along the river?

The key questions are elaborated in the following questions: (1) How are social structures, social norms, social values, habits, and patterns of social relationships run by riverbank community? (2) How are the public perception of flood, the ecological environment, the pattern of mastery of natural resources, economic resources and social resources in the riverbank community? (3) How are the economic, social, and cultural community strategies built by riverbank community? (4) How are the approach and strategy of social modification to empower riverbank communities that are implemented by government and other stakeholders? (5) How is the social modification model for the empowerment of riverbank community in accordance with the internal and external environmental conditions?
The research questions were arranged in the form of guiding questions with data collection from the field. Guiding questions were flexible and became the early guideline for the researchers. When the study started, the researchers looked at the reality which took place in the real cases. The questions could be changed and sharpened during the study. The decision to sharpen and to change the questions was based on the results of researchers' observation during the study. Therefore, in a qualitative study, the researchers also served as the instrument of study. The instrument reliance which was on the researchers (not on the questionnaire or survey sheets) helped the researchers to work based on facts and data encountered in the field, not just fulfillment of the questionnaire that had been prepared behind the desk. In a qualitative study, it is important to be able to capture the real problems in society and government institutions.

A qualitative approach gave an open and flexible space to explore data through in-depth interview, participatory observation, focus group interview, and focus group discussion. The process of deepening the data was always associated with a theme related to the economic, social, and cultural strategies which were experienced/run by the society, government, and other stakeholders. The exploration of the data was conducted progressively by relying on the formulations of progressive and contextual questions. The process of deepening the data and information depended on confidence on the researchers, whether the obtained data and information were sufficient to explain the problem and research purposes. Time limitation also influenced the process of data collection.

\section{RESULTS AND DISCUSSION}

This section specifically presents the results and discussion of research which are aimed at two main focuses, namely: The first is the background of the physical and ecological conditions experienced by communities along the Ciliwung River. Physical and ecological conditions affect the settlement patterns and socio-economic strategies 
which are run by society. Related to this, the government-run social intervention actually puts more emphasis on the provision of emergency assistance and the slow pace of efforts to encourage innovative changes. The second is the overview of the socio-economic strategies that are run by the river bank community as the response to the flood which occurs repeatedly in the long term.

\section{Physical Setting and Social Intervention} The preliminary research finding shows that the total area of Jakarta is 66.152 million hectares (or approximately $662 \mathrm{~km} 2$ ). On the area, there are about 13 flowing rivers which have branches and sub-branches. Total numbers of the river with branches and sub-branches which pass through the region of Jakarta are 29 rivers. Out of these, as many as $83 \%$ of them, have poor quality water and about $17 \%$ of them have the moderate quality water. The data from the Ministry of Housing in 2012 shows that the numbers of households who live at the Ciliwung river bank are 34,051, spreading in 13 villages. In Cawang village, the numbers of households who live at the Ciliwung river bank are 1,623 households, spreading in $6 \mathrm{RW}$. In Kampung Melayu, the numbers of households who live along the river are 7233 households, spreading in 6 RW (see BPDAS CitarumCiliwung, 2009; Irawaty, 2012; Anonymous, 2014).

The area of Ciliwung river bank crosses the middle of the city after crossing the region of Bogor Regency, Bogor City, and Depok City. The development in the upstream region and in the city area which are traversed by Ciliwung river has damaged the river bank and removed the absorption power of more than $80 \%$. Until 1980, the watersheds that had changed the function were 18415.26 ha consisted of housing area (10857.63 ha), industrial zones (4960.05 ha), and trading services (2596.58 ha). About 13 banks of rivers in Jakarta are the sources of public land for settlement basis. Most residential/housing in Ciliwung riverbanks are included in the category of slums because of the poor quality of their basic infrastructure. Ciliwung river bans conditions contribute to the slum condition of $392 \mathrm{RW}$ and 64 poor villages in Jakarta (see BPDAS CitarumCiliwung, 2009; Irawaty, 2012; Anonymous, 2014).

The result of interviews with some people has not shown the same information about the time of routine flood which began to afflict the lives of people in Ciliwung riverbanks. Most people claim that the flood began to occur regularly from the mid1980s. Before the mid-1980s, the Ciliwung flood did not severely interfere with people's lives. The flood only occurred when it rained and immediately flowed downstream so the water puddle did not occur in a long time. The variation of people's experience on the starting point of regular flood in Ciliwung is understandable because people have the different experience of staying on the $\mathrm{Ci}$ liwung bank.

Through the program of "Jakarta Urgent Flood Mitigation Project" and Normalization program of Ciliwung, the government seeks to address a variety of routine and chronic problems in the river bank area. Through these two programs, the problem of flood is mitigated through an improved river bank and catchment. The programs are also expected to solve the problems of housing and social/economic of river bank community. The program of housing development is one of the breakthrough series, although the side impact should be anticipated. Through the Environmental Improvement of settlement Program, the Jakarta administration also continues to improve slums and alleviates poverty in the villages which are identified as poor community. Some Jakarta government programs which give emphasis on the technical construction process are always in contact with mental construction process to strengthen the sustainable strategy of socio-economic and ecological-environmental restoration (see Mikmah 2010; Arifianto, 2009).

The news of river normalization program finally arrives in Ciliwung riverbanks community. However, until now, the community has not directly received an explanation from the government. The information is still confusing; whether their residential 
areas will be affected by the normalization and centralization of settlements through flats housing. By comparing the extracting information gained informally by researchers, there are differences in the public response to the plan of Ciliwung normalization. In the previous years, when talking about Ciliwung normalization plan, people did not pay serious attention because they thought that these projects would be only a discourse and still got to their settlements in a long time. It is different when the interviews are conducted now, the people give serious attention because they see the government realizes the seriousness of the Ciliwung River normalization project. However, the complaints that arise are mainly because there is no serious discussion about the certainty of the river normalization project. Most people whose houses are flooded because they are located on the river will give up if the normalization project comes to their area. The major concern of society is the certainty of compensation and business continuity/their livelihood.

The data analysis shows that there are no special services from the government toward the needs of society, in terms of health, water, and waste management. Although the routine flood has disturbed the public health and water supply, there is no special care from the government. The nearest health service is centered on the health centers at the village and district level. The health services at Posyandu (especially for Toddlers and Elderly) which are based in the village, although they are close and easily accessible but the service is always interrupted/disturbed during flood because Posyandu staffs are normally part of the flood victims. In fact, the urgency of the need for health services for river bank community especially occurs during the flood.

The basic educational facilities are located on the banks of the river so that they are always stopped providing services to the public during the flood. Interruption of these services in addition to the educational facilities being flooded, often these facilities also become places for refuge residents affected by the floods and most of the care workers are also victims. The approach of the government services which are stiff and formal are difficult to cope with the emergency conditions during the flood. Government officials at the village state that their position as officers in the field are often trapped in a dilemma situation. On one hand, they know the condition of the community needs to be served immediately, but on the other, the administrative procedures are often not ready. Long-winded process must be taken to avoid the risk of administrative violations that adversely affect their careers.

In overcoming the limitations of such services, the initiative appears from the community by establishing Ciliwung Studio as a non-profit organization to serve the needs of public health. Likewise, to provide services for education, community initiate to establish the Women community School of Ciliwung to specifically serve informal education for women about health, cooperation, and business skills. For increasing their public awareness in the fields of politics, democracy, and rights of access to economic resources, they establish Merdeka Ciliwung Studio. The initiations of community to encourage the fulfillment of basic needs and basic rights of the people take place and are set at the center of settlements along the river Ciliwung (see Mikmah 2010; Arifianto, 2009).

The overview of government service is an irony. Big flood that comes regularly in the center of the national capital is responded traditionally and not innovative. Some time ago, the government of Jakarta held a massive preparation to cope with flood. This initiation is a celebration to the death of a strategic idea which shows the government concern in seriously mitigating the flood. Unfortunately, the action just touches the outer points. The government quickly allocates a budget for flood prevention. Food, medicine, tents and inflatable boats can be prepared quickly. Political parties quickly help because they can take advantage of the event. Although their supports are only noodles and mineral water, but the identity of the party banners and pictures of party leaders must be large and placed in strategic 
places. Those actions do not touch the fundamental issue to prevent flood, such as the conservation of upstream area, cross-region cooperation, organizing settlement patterns and arranging a convenient drainage network (see Maring, Maring 2006 and 2007).

\section{Community Social Strategy}

Preliminary result of this study shows that the origin of residents of Cawang village and Kampung Melayu who live along the Ciliwung river bank comes from various regions in Indonesia. So far, it has been identified that most citizens of Ciliwung river bank come from Java, Sunda, North Sumatra, Sulawesi, Kalimantan, Nusa Tenggara Timur, and Betawi as the native of Jakarta. The research results show that there is no community which appears dominant in the construction of social structure along the river Ciliwung based on such origin. Therefore, there is no effect between origin basis of the community toward the construction process of social structure on the Ciliwung riverbank.

So far, it appears that the construction process of social structure takes place within that intra-group based on the origin. The phenomenon is visible through the activities and social interactions which are built in each category based on the residents' origin. Residents who come from the same area build relationships and specific relationship between fellow friends through family gathering activities, social activities, and fellowship (religious worship). The ongoing process that is slowly forming patterns of relationship and social relationship is typical among those who have a common origin. This process gradually generates a situation in which they know each status and position in their intra-group. Each group creates mutual understanding; who has the stronger economic status as compared to the others, who has professional excellence in a particular field, who should be assisted/reinforced in economic, education, and health affairs. However, the process of building relations and intra-group interaction is not only taking place exclusively within the territory of the riverbanks, the process is extensive by involving citizens' origins who live outside the river banks. The process of building relationships and social interactions that are spread out may explain why there is no behavior of the dominant culture (culture dominant hypothesis) in public life along the river (see analysis Lubis, 2005).

The phenomenon of the relation pattern and intra-group interactions (in small groups, limited, special, and specific) is taking place in the context of faith and religious similarities. According to the interview, in response to the procedure of running their religious life that is unique and different, so in public life along the river is also creating patterns of relationship and interaction based on religious similarities. Religiousbased groups are not only based on religious rituals in places of worship such as mosques and churches, but also in social life. In addition to the fellowship of the community to support the religious rituals, they also form alliance groups based on faith in social life through regular meetings, social activities, recreation, and reflection together.

Similarly happening in the relationship/origins-based interaction, the process of building relationships and faith-based intra-group interaction is not only taking place exclusively within the territory of the riverbanks, the process is extensive, involving also the residents in the area beyond the riverbanks. The process of building relationships and social interactions that are spread may explain why there is no visible pattern of dominant cultural relationships in people's lives along the river. However, a more convincing analysis of this phenomenon still requires data exploration in the next research phase.

Beyond relations/social interaction that are built based on common origin and religious basis, empirical reality shows the establishment of relations-interactions pattern which are trying to bridge the social structure to accommodate the relations interactions into a broader construction. The effort to build a broader social structure construction takes place through a process which is characterized by both informal and formal process. Society deliberately de- 
velops patterns of relationship-interaction by dynamically bridging "smaller" groups through formal activities and social activities that involve all citizens at the local level. Through the role of government officials, community leaders, and religious leaders, various social activities that involve all citizens in the area of Tanjung Sanyang are carried out. Through the role of RW and RT staffs, they can give comfort to the residents. The formal and informal leaders have also carried out social activities such as routine gathering of citizens called "Awet" involving "Gentlemen". Through this social gathering, social issues are discussed at the regional level and their solutions. There is also a social gathering at the neighborhood level "mothers" which are carried out routinely.

The dynamics of community life in small group level and in the context of wider region simultaneously construct the values and norms to hold onto in living together. The process which occurs shows that the basis of values and norms that construct and operate the community on the river banks comes from religious values and norms, origin values and norms, and formal values and norms which come from the common goal of life initiated by government officials at the level of RT / RW. Hypothetically, the success has opened up the boxes that values and norms to be held together in society. Otherwise, the failure of removing the box and limits of such values and norms can create resistance and "stiffness" in the dynamics of social life. However, we still recognize that we need to find the necessary data/information to strengthen the analysis of the construction process of values and norms which take place in public life along the riverbank.

The important lesson from the process of building relations, social interaction, community which are run by the riverbank community is the creation of the social structure construction which consists of several layers, repetitive and overlapping roles as a response to the realities faced because of flood faced by the riverbank communities. The social structure which is built is always oriented to help each other and relieve the pressure caused by flood. A citizen should be involved in a variety of organizational structures that exist as a strategy to secure themselves. This situation enables the social structure which is built to have flexibility and avoid from the social deviations.

Social structure which is built does not aim to strengthen the particular positions, but to help the weak ones. On the other sides, society through government officials and public figure must be able to encourage the groups which are growing through activities and structure construction which are "bigger-wider" by emphasizing the importance of communal agenda which is wider in terms of scope area.

\section{CONCLUSION}

The community of Ciliwung river bank as the research location has social organizations based on origin, religion, and has characteristics of informal and formal-administrative. Social organizations, although are based on religion and origin, but are still inclusive and oriented to solve the social problem on their daily lives. Society, through the role of government officials and public figure, must be able to encourage the groups which are growing within society through activities and structure construction which are "bigger-wider". However, social organizations which are built have not directed to improve productivity of society, in contrary, are directed to secure the emergency situation which is faced by society in responding the repeated flood.

The social strategies which are implemented by Ciliwung River bank community are influenced by the routine flood in a long period of time. The pattern of adaptation is involutive which is shown within the applied strategy. This involutive pattern affects and hinders the society decision to find innovation and change including in normalization agenda and settlement management of $\mathrm{Ci}^{-}$ liwung river bank community. The program of government social service is stuck in the social program scheme which is emergent, not strategic and non-sustainable. This situation, in one hand, hinders the social service, and on the other, creates social doubt 
from the government program in managing Ciliwung river bank. Through independence program of the community, the society is able to create innovation in responding the real need in society through the development of community-based organization to specifically manage the society in education, medication, economic fields, and the political awareness and their rights.

Referring to the above discussion, there are some conclusions: (1) social intervention program to conduct social modification must be taken into account and accommodate the social dynamics and economy-social strategies of Ciliwung river bank community. (2) The social intervention program and Ciliwung river bank management must be oriented to empower the economy-social strategies of community, especially in preserving their sustainability of jobs.

\section{ACKNOWLEDGEMENT}

Thanks to the Ministry of Education of Republic of Indonesia which has financially support this research through Keputusan Direktur Penelitian dan Pengabdian Kepada Masyarakat No 0263/E5/2014 about the decision of research grant winning for private universities lecturers Kopertis area III Jakarta 2014 No: 213//K3/KM/2014, 7 Mei 2014.

\section{REFERENCES}

Arifianto, S. dan Virhani, M.R, 2009. Informasi Bencana dan Budaya Lokal (Kasus Penanggulangan Banjir di Kelurahan Bukit Duri Jakarta Selatan). Puslit Aptel SKDI Balitbang Sumber Daya Manusia, DepKomInfo. Sumber: http:// balitbang.kominfo.go.id/balitbang/aptikaikp/files/2013/o2/KAJIAN-BENCANA-BANJIR-JAKARTA.pdf. Akses: 4 Nopember 2014.

Anonim. 2014. Komunitas Ciliwung Condet: Konservasi DAS Ciliwung. Sumber: http://komunitasciliwungcondet.blogspot.com. Akses: 9 Nopember 2014.

BPDAS Citarum-Ciliwung. 2009. Laporan Akhir Tahun: Penyusunan Rencana Detil Penanganan Banjir di Wilayah JABODETABEKJUR. Kementerian Kehutanan, Ditjen RLPS, BPDAS Citarum-Ciliwung. Sumber: http://bebasbanjir2025.wordpress.com/konsep-pemerintah/ bpdas- citarum-ciliwung/. Akses: 4 Agustus 2014 .

BPS. 2012. Penduduk DKI Jakarta Berdasarkan Kecamaan. Badan Pusat Statistik Provinsi DKI Jakarta.
Christanto, J. 2010. Strategi dan Rencana Aksi Pengembangan Pelayanan Sosial Perkotaan dalam Rangka Meningkatkan Daya Dukung di Kawasan di Wilayah DKI Jakarta, Jurnal Ekosains, Vol. II No. 1, Maret 2010.

Creswell, J. W. 2010. Research Design: Pendekatan Kualitatif, Kuantitatif, dan Mixed, Edisi Indonesia. Yogyakarta: Pustaka Pelajar.

Geertz, C. 1963. Agricultural Involution: The Process of Ecological Change in Indonesia.Berkeley: University of California Press.

Irawaty, D.T. 2012. Diskusi Normalisasi Sungai Ciliwung. Sumber: rujak.org/2012/o8/diskusinormalisasi-sungai-ciliwung. Akses: 4 Agustus 2014.

John W. C. 2010. Research Design: Pendekatan Kualitatif, Kuantitatif, dan Mixed, Edisi Indonesia, Yogyakarta, Pustaka Pelajar.

Karim, C. 2007. Banten dan Involusi Peradaban Kehidupan di Desa. KOMPAS: 17 September 2007.

Khasan, M., dan Widjanarko, M. 2012. Perilaku Coping Masyarakat Menghadapi Banjir. Jurnal Psikologi Pitutur, Volume I. Nomor 2, Juni 2012.

Lipsky, M. 1980. Street Level Bureaucracy: Dilemmas of the Individual in Public Services. New York: Russel Sage Foundation

Lubis, Z. 2005. Kanalisasi Ketegangan Etnik dan Kompetisi Budaya dalam Sektor Publik, Jurnal Antropologi Sosial Budaya, ETNOVISI, Vol. 1, Nomor 2, Oktober 2005

Maring, P. 2009. "Involusi dan Transformasi Pertanian NTT: Sebuah Sudut Pandang Antropologi Ekologi”. Orasi Ilmiah pada Dies Natalias Politeknik Pertanian Negeri Kupang. . 2007. "Involusi Kekuasaan", Opini, Jakarta: Harian KOMPAS: 5 Juli 2007. . 2007. "Banjir Berulang dan Jerat Kemiskinan", Opini, Jakarta: Harian Seputar Indonesia: 16/2/2007. . 2006. "Banjir dan Perilaku Manusia”, Opini, Jakarta: Harian Seputar Indonesia:30/12/2006.

Mikmah, S.K. 2010. Studi Sungai Ciliwung Pengabaian Pemerintah Terhadap Eksistensi Penduduk Pinggir Sungai: Wajah Pengelolaan Sungai di Indonesia, Jakarta: INFID (International NGO Forum on IndonesianDevelopment). Sumber: konservasidasciliwung.files.wordpress. com /2012/05. Akses: 4 Agustus 2014.

Saifuddin, A. F. 2005. Antropologi Kontemporer: Suatu Pengantar Kritis Mengenai Paradigma. Jakarta: Prenada Media. . 2007. Kemiskinan di Indonesia: Realitas di Balik Angka. Orasi Ilmiah dalam rangka Pengukuhan Sebagai Guru Besar Antropologi FISIP UI, 24 Januari 2007. Universitas Indonesia. 2009. Refleksi Pemikiran Geertz: Involusi Pertanian, Involusi Kita. Sumber: Kompas Cyber Media: www.duniaesai.com/antro. Akses 12 Oktober 2009.

Suminar, S. et al. 2011. Strategi Penyusunan Pola Tata 
Komunitas Berbasis Partisipasi Masyarakat Bantaran Sungai Winongso, Jurnal Penelitian BAPPEDA Kota Yogyakarta, No. 6 April 2011, ISSN 1978.0052.

Suparlan, p. 2004. Masyarakat dan Kebudayaan Perkotaan: Persektif Antropologi Perkotaan, Yayasan Pengembangan Kajian Kepolisian.

1999. Kemajemukan, Hipotesis Kebudayaan Dominan, dan Kesukubangsaan." dalam Jurnal Antropologi Indonesia No. 58 Thn 1999.

Tim Ekspedisi Ciliwung KOMPAS. 2009. Ekspedisi Ciliwung: Laporan Jurnalistik Kompas, Jakarta: Penerbit Kompas. 